\title{
TOURISM BASED ON DISASTER MITIGATION IN ANYER, SERANG REGENCY
}

\author{
Marningot Tua Natalis SITUMORANG ${ }^{*}$ \\ ${ }^{1}$ Faculty of Engineering, Sahid University, Indonesia \\ *uchoxs@yahoo.com
}

\begin{abstract}
The beach in Anyer Serang is an area with a very famous marine and coastal natural tourism destination and is visited by many tourists. However, after the tsunami in December 2018, the number of tourists coming to Anyer decreased. This is because there is no guarantee of safety if tourists visit this area, lack of information about the disaster mitigation system, and the unavailability of signs/signs where and how to go when a disaster occurs, such as: evacuation routes, evacuation sites and so on. The objectives and targets of this Community Service activity are: (1) to find out whether visitors, traders, fishermen and local communities are given knowledge about disaster mitigation; (2) provide knowledge about disaster and disaster mitigation to visitors, traders, fishermen and local communities; (3) evaluation of knowledge about disaster and disaster mitigation in the tourism area of Anyer, Serang Regency. This activity uses a tourism method based on individual disaster mitigation which is carried out directly at tourist attractions. In its implementation this method begins with interviews with visitors, traders, fishermen and local communities about tourist sites and disaster mitigation from entrances to exits, and several alternative evacuation routes, and several events that have occurred and may occur, then lectures - discussions (ask responsibility) related to disaster and disaster mitigation, then evaluate the knowledge of visitors, traders, fishermen and local communities about disasters and disaster mitigation. The location of this community service implementation is the Green Garden Resort Anyer tourist area, Serang Regency. This Community Service activity was carried out for visitors, traders, fishermen and local communities in April 2020. From the activities carried out, it can be concluded that the knowledge of tourists, traders, fishermen and local communities about disasters and disaster mitigation is still lacking, especially supported by the absence of guidelines. /sign disaster mitigation.
\end{abstract}

Keywords: Disaster, Tourism, Disaster Mitigation, Disaster Mitigation Non Structural

\section{BACKGROUND}

Law Number 24 of 2007 states that a disaster is an event that threatens and disrupts people's lives and livelihoods caused by natural factors, non-natural factors and human factors that cause casualties, damage to the environment, property losses and psychological impacts. Disasters consist of: 1) Natural disasters, namely disasters caused by events or a series of events caused by nature, including earthquakes, tsunamis, volcanic eruptions, floods, droughts, hurricanes, and landslides. 2). Non-natural disasters are disasters caused by events or a series of nonnatural events which include technological failures, failed modernization, epidemics and disease outbreaks. 3) Social disaster is a disaster caused by an event or series of events caused by humans which includes social conflict, between groups or between communities and terror.

According to Sugandi in Cut, Muzar, Fithria, \& Syarifah (2019), disasters in Indonesia can reach more than 1,000 times a year or reach 3 times a day. In 2019, the number of disasters in Indonesia reached 3,721 incidents with 477 deaths, 109 missing, and 3,415 people injured. The impact of the disaster caused varied such as damage to houses, health facilities, personal facilities and educational facilities (National Disaster Management Agency, 2020).

According to Chatarina (2012) victims of natural disasters will face physical problems such as disruption of meeting the needs of food and drink, shelter, health and education. Meanwhile, psychosocial problems faced such as deep loss of the death of a family member, loss of property and sources of livelihood that caused prolonged sadness felt by the victim.
Disaster victims who survive will experience psychological impacts in the long term and affect psychological well-being when carrying out daily activities (Davidson \& Mcfarlane in (Dwi, Mustikasari, \& Ria, 2020).

Mitigation is a series of efforts to reduce disaster risk, both through physical development as well as awareness and capacity building to deal with disaster threats. Mitigation consists of physical (structural) and nonphysical (non-structural) mitigation. Physical mitigation is in the form of infrastructure development and natural prevention in the form of tree planting, while non-physical mitigation is in the form of education and training, zoning and warning signs. (Law 24, 2017). Disaster victims are at risk of experiencing trauma that results in stress disorders as much as 3.8\% compared to other traumatic events, Mendatu Dalam (Elyusra, 2013). However, disaster mitigation that has not been comprehensive has become a problem for the entire community (Ida, Putu, \& Kadek, 2019).

Disaster mitigation when dealing with disasters in Indonesia has not been implemented properly due to the lack of socialization from Government Institutions or NonGovernmental Institutions, thus exacerbating the condition of the people affected by the disaster (Dewi, 2020). The condition of community unpreparedness in dealing with disasters is caused by the lack of efforts made by the government or other parties due to the limited resources they have (Paramesti, 2011). Ramli, Sri, Sari, \& Dirhamsyah (2014) argue that the large number of casualties due to disasters is due to the lack of public knowledge about disasters and preparedness when anticipating disasters that occur.

The potential of abundant and attractive marine natural resources for tourists also has the potential to be 
a threat, because it is prone to disasters. The marine and coastal areas in Anyer are marine tourism areas that have become a major tourist destination or destination in recent years.

Local communities who become tourism actors get a fairly large social and economic impact with an increase in the number of tourists who come. However, after the Mount Anak Krakatau tsunami occurred in December 2018, the number of tourists who came has decreased considerably. The main cause of the decline in the number of tourists is the lack of safety guarantees if they visit this area, this is due to lack of information about early warning systems, lack of public knowledge in disaster management and the unavailability of infrastructure that becomes a place of protection when a disaster occurs, such as: evacuation routes, shelters etc.

The objectives and targets of this Community Service activity are: (1) to find out the knowledge of visitors, traders, fishermen and local communities about disasters and disaster mitigation in tourist areas. (2) providing knowledge and understanding as well as creating a culture of tourists who are alert and adaptive to disaster threats; (3) evaluate the knowledge of disaster risk reduction in the tourism area of Anyer, Serang Regency. In its implementation, this method begins with interviews with visitors, traders, fishermen and local communities regarding tourist sites from the entrance to the exit, and several alternative evacuation routes, and several events that have occurred and may occur, then lectures - discussions (questions and answers). - and on-site evaluation. The advantage of this method is that participants can immediately find out about disasters and disaster mitigation by hearing and seeing directly, while the drawback is that they tend to depend on interviewers and maybe this is only an obligation for them as participants in community service programs. The benefit of this activity is to prepare visitors, traders, fishermen and local communities who know about disasters and are responsive when disasters come and can save themselves.

The location of the service area is at Green Garden Resort Anyer, Serang. The Anyer area is located in Anyer
District, Cikoneng Village, in the West End of Serang Regency, Banten Province. The main tourist attraction in this area is the long and wide coastline, facing the Sunda Strait, generally a coast covered by coarse sand, fine sand and gravel, the beach seen from its morphology is a wavy area with a slope of $0-15 \%$ with a depth of the sea is 0 $\mathrm{m}$ to $15 \mathrm{~m}$, the speed of the water current is about 24.62 $\mathrm{m} / \mathrm{second}$. Below is a picture of the location of the Green Garden Resort Anyer beach and its surroundings.

\section{METHOD}

\section{Implementation Method}

The method used in this community service is an individual-based non-structural disaster mitigation method that is carried out directly at tourist attractions. The aim is to seek information from tourists, traders, fishermen and local communities about tourist sites and evacuation routes in the event of a disaster, then lectures and discussions about disaster and disaster mitigation, and then evaluates their knowledge about disasters and mitigation in the tourist area. With this method, it is hoped that there will be an increase in their knowledge, skills, attitudes and behavior so that if a disaster occurs they will not become victims.

In its implementation, this method begins by interviewing visitors, traders, fishermen and local communities regarding disasters and disaster mitigation at tourist sites from the entrance to the exit, and several alternative evacuation routes, and several events that have occurred and may occur, then lectures discussion (question and answer) - then evaluate knowledge on the spot. The advantage of this method is that participants immediately see and practice what mitigation is, while the drawback of this method is the tendency of participants to consider this only an obligation as participants.

Non-structural disaster mitigation is a learning process that is carried out outside formal education both by the government and by the community with the aim of helping and guiding the community in this case visitors, traders, fishermen and local communities so that they are able to make decisions in overcoming the disasters they

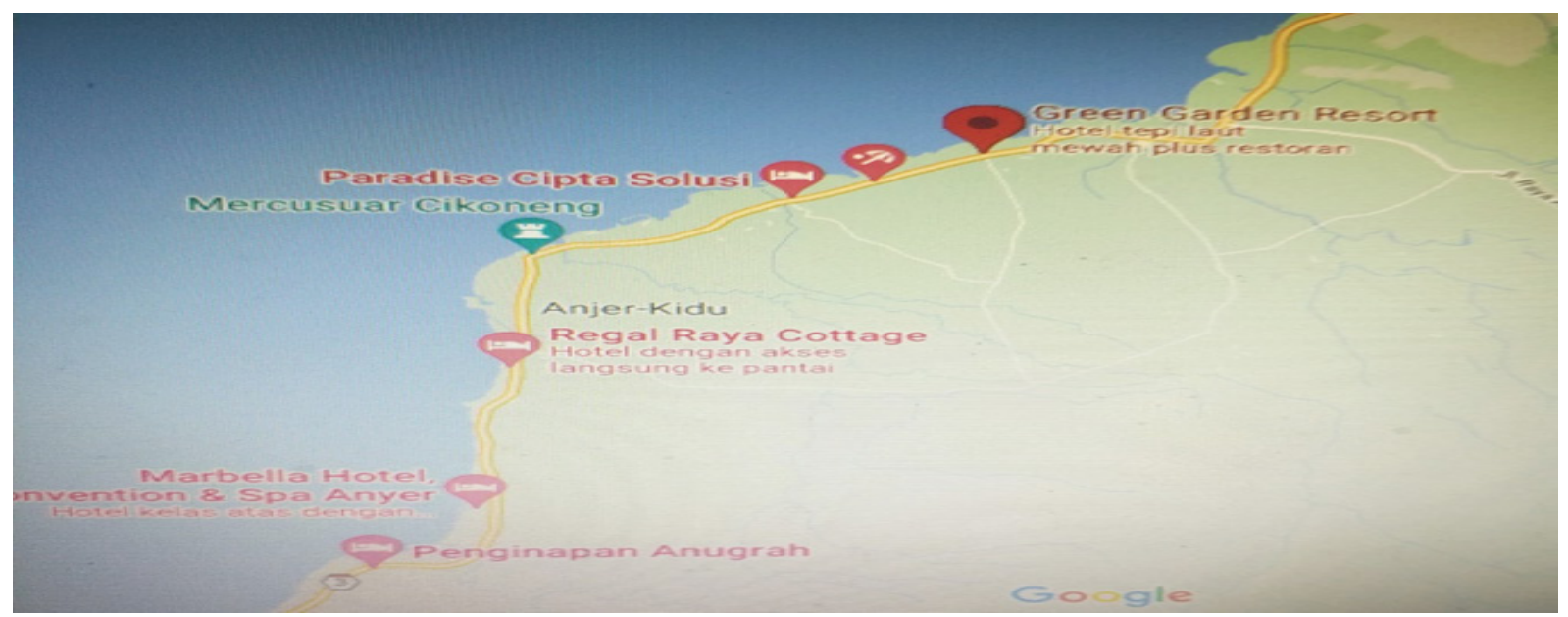

Figure 1. Map of Anyer . Integrated Tourism Area 
face. The better non-structural disaster mitigation, the more effective the achievement of objectives. To determine in advance whether a disaster mitigation can be called good, a benchmark is needed that comes from several factors. The main determining factor is the goal to be achieved in disaster mitigation, because disaster mitigation is part of learning.

Non-structural disaster mitigation referred to in this community service activity is disaster mitigation which in practice is carried out directly at the implementation site (visited tourist area).

\section{Program Socialization and Consolidation}

The socialization and strengthening of the program will involve stakeholders consisting of visitors, traders, fishermen, local communities around the location. At this stage, lectures and discussions are held on disasters and disaster mitigation

\section{Evaluation of the Implementing Party}

After the interview and following the socialization on disaster and disaster mitigation, visitors, traders, fishermen and local communities were given a test on their knowledge of disaster and disaster mitigation, evaluation of those who carried out these activities.

In the implementation of the community service program, the meeting which was held on April 26, 2020, the team together with all parties involved carried out all activities as expected.

\section{RESULTS AND DISCUSSION}

Interviews with Visitors, Traders, Fishermen and Local Communities in Anyer, Serang Regency:
1. The first stage is a study of the main issues, causes, impacts and alternative disaster management. The results of this activity are Table 1 below.

2. The second stage is lecture and question and answer (interactive dialogue) and post test.

Based on the results of interviews and post-tests, it can be concluded that most of the visitors, traders, fishermen and local communities around tourist sites have begun to recognize the potential for disasters including earthquakes and tsunamis. However, they still have difficulty recognizing the signs of the earthquake and tsunami disaster. If viewed broadly, they do not have a high enough level of mitigation seen from the answer to the question of the first thing to do when the earthquake and tsunami occur. This is supported by the lack of signs regarding access to evacuation sites and alternative evacuation locations.

Some things that are lacking based on the test results are the absence of a sign for the type of potential disaster in Anyer, Serang Regency, a disaster mitigation poster and a sign for disaster evacuation locations. This deficiency can be seen in the respondents' answers at the interview stage, which shows that so far there has been no official disaster evacuation simulation or training for them. Based on the results of interviews with those who have visited the Anyer tourist attractions several times, so far the managers of tourist attractions have used microphones only as a medium to inform signs of safe swimming locations.

3. The third stage is a plan for preparing a disaster evacuation route and a plan for making signs (disaster mitigation signs).

Table 1. Main Problems: Issues, Causes, Impacts and Alternative Treatments

\begin{tabular}{|c|c|c|}
\hline REASON & IMPACT & ALTERNATIVE HANDLING \\
\hline \multicolumn{3}{|c|}{ Issue: Explanation of tourism related to disaster } \\
\hline \multicolumn{3}{|c|}{ Incidents that have happened and may occur in tourist attractions } \\
\hline $\begin{array}{l}\text { - Tzunami December } 2018 . \\
\text { - Mangrove logging } \\
\text { - Indiscriminate garbage disposal } \\
\text { - Oil spill } \\
\text { - The number of fishing gear } \\
\text { that destroys the environment } \\
\text { - The number of residents who } \\
\text { build buildings on the coast line } \\
\text { - Lack of public awareness of } \\
\text { the importance of environmental } \\
\text { sustainability } \\
\text { - Low level of education } \\
\text { - Lack of community participation }\end{array}$ & $\begin{array}{l}\text { - The decline in the catch of } \\
\text { fishermen } \\
\text { - The destruction of marine life and fish } \\
\text { - Floods during the rainy season } \\
\text { - Infertile soil } \\
\text { - Dryness of clean water in the dry season } \\
\text { - Coastal erosion and loss of natural coastal protection } \\
\text { from the threat of tidal waves and tsunamis } \\
\text { - Disposal of any waste } \\
\text { - Illegal logging } \\
\text { - Marine pollution and abrasion } \\
\text { - Welfare decreases } \\
\text { - Lack of tourist visits } \\
\text { - Destroyed forest }\end{array}$ & $\begin{array}{l}\text { - Counseling on the importance of disaster } \\
\text { mitigation and environmental preservation } \\
\text { - There needs to be a village arrangement } \\
\text { (spatial layout) } \\
\text { - Formed coastal and mangrove security } \\
\text { groups } \\
\text { - Regulations on activities around the beach } \\
\text { environment } \\
\text { - Law enforcement } \\
\text { - Gotong royong / community service } \\
\text { - Making trash cans } \\
\text { - Waste management } \\
\text { - Enforcement of rules/agreements }\end{array}$ \\
\hline \multicolumn{3}{|c|}{ Issue: Signs/instructions related to Tourism Disaster Mitigation } \\
\hline \multicolumn{3}{|c|}{ Handling of tourism objects that are not optimal } \\
\hline $\begin{array}{l}\text { - Lack of signs/signs/instructions } \\
\text { in supporting tourism activities } \\
\text { - Environment (sanitation) that is } \\
\text { less supportive } \\
\text { - Lack of education and community } \\
\text { participation in tourism } \\
\text { - Damaged Road for evacuation }\end{array}$ & $\begin{array}{l}\text { - Existing potential is difficult to develop } \\
\text { - Many children drop out of middle and high school } \\
\text { level } \\
\text { - The quality of human resources is relatively low } \\
\text { - Difficult to get a job } \\
\text { - The mindset of the community is very limited so that } \\
\text { it affects village development }\end{array}$ & $\begin{array}{l}\text { - Development of basic infrastructure for } \\
\text { mitigation } \\
\text { - Asking for support from various parties to } \\
\text { make a sign } \\
\text { - Conducting outreach to the community } \\
\text { about tourism and mitigation } \\
\text { - Develop tourist attractions such as hunting, } \\
\text { fishing, diving, mountain climbing, etc. }\end{array}$ \\
\hline
\end{tabular}


This community service activity with the theme of disaster mitigation is closed with what the expectations of visitors, traders, fishermen and local communities are for the implementers. The hope is that to improve their safety, the tourism area must make posters and signs for disaster mitigation. Activities at this stage will be carried out by making an action plan with the main consideration being the answers of visitors, traders, fishermen and local communities to interviews that will be submitted to various parties who are expected to support.

The outputs of this community service program are: 1) Preparation of a simple and short Module on disaster and disaster mitigation that can be implemented by visitors, traders, fishermen and local communities.

2) Making an Evacuation Path Map and sign for Disaster mitigation at Anyer beach, Serang Regency as a guide and guide to tourists and local communities regarding evacuation locations to improve disaster mitigation independently. In this service activity, efforts are made to collect data and identify evacuation routes as a source of information in making disaster mitigation signs. From the results of the field survey, it was found that almost all locations that have high contours and do not have a stable structure can be used by visitors and local residents to go to higher ground but the sign to get there is no longer there.

One of the tsunami evacuation routes is located in Cikoneng Village, Anyer. Now, the condition of the tsunami evacuation route is very alarming. The line was badly damaged. Based on information from the community, the route is traversed by large trucks so that it has holes and is flooded with water when it rains.

Although it has been damaged for years, the local government has not yet repaired it.

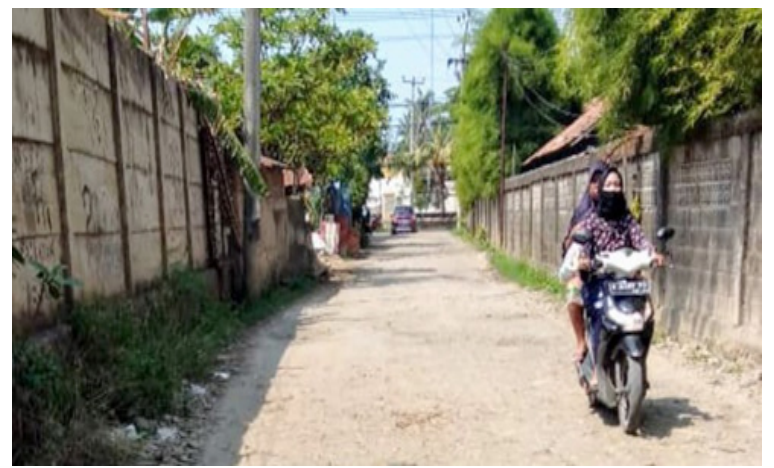

Figure 2. Condition of the tsunami evacuation route in Cikoneng Village, Anyer, Serang Regency

(Source:merdeka.com, 2020)

From the results of observations at the activity site, a sign system for the tsunami evacuation route was found. Because the number is very limited, making it difficult to find, the conditions are no longer suitable for continued use, and the sign system in this location was created without using standard theories of making a good sign system.
A sign system is a collection of individual signs that have been designed to identify or direct. The signs used in a sign system basically express the meaning of the rules which are international standards, so that it will be easy for everyone to understand (Phill Boines, 2008; 17).

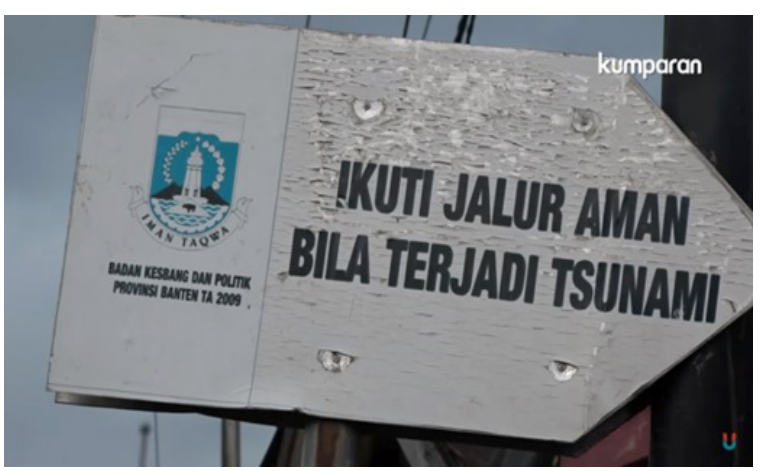

Figure 3. Signs of the Disaster Evacuation Path in Cikoneng Anyer Village, Serang Regency

(Source: coil.com, 2019).

This community service program was carried out to 30 tourists, traders, fishermen and local communities who were directly selected (accidentally) and considered to have represented. They were interviewed while walking down the tourist attractions, then invited to the hut to attend a lecture, after which they were given a test.

\section{CONCLUSION}

Based on the results of this community service activity, it can be concluded that the knowledge of tourists, traders, fishermen and local communities about disasters and disaster mitigation already exists. However, in the absence of a disaster evacuation sign, their preparedness in dealing with disasters can be in vain because of their wrong actions. Through disaster mitigation-based tourism, it is hoped that not only tourists, but traders, fishermen and the local community will also be assured of their safety and that the sustainability of tourism as a source of the economy of the community in Anyer will continue.

Some suggestions related to community service are as follows:

1. There needs to be an active role from all parties, especially the owner or manager of the tourist area along with other stakeholders such as BPBD, Regency and Provincial Governments, Hamlet and Village Officials, community organizations, the private sector (tourism industry) and the community in improving disaster mitigation.

2. In realizing a disaster mitigation system, it is necessary to collect data on potential disasters, as well as make signs. The next action plan can be used as a guide and standard in realizing disaster response tourism in coastal areas in Anyer, Serang Regency and other coastal areas.

3. Along with the times, it is necessary to improve disaster evacuation infrastructure such as repairing evacuation routes, determining evacuation location points in stages, building permanent evacuation shelters to adding an early warning system (EWS) 
4. Provision of educational media and disaster evacuation in the form of sign boards, posters that can be socialized and applied in public locations such as schools, village halls, tourism information centers, places of worship which are placed evenly in all areas in Anyer, Serang Regency.

\section{ACKNOWLEDGMENT}

Thank You For The Research And Community Service Institution (LPPM) Sahid University Jakarta For The Support And Funding This Program.

\section{REFERENCES}

Ashar, F., Amaratunga, D., Haigh, R. 2018. Tsunami Evacuation Routes Using Network Analysis: A case study in Padang. Procedia Engineering 212 (2018) 109-116.

Manjarrez, A. J., Wickliffe, L.C. \& Dean, A., eds. 2018. Guidance on spatial technologies for disaster risk management in aquaculture. Summary version. Rome, FAO. 34 pp.

Moreno, J., Lara, A., Torres, M. 2019. Urban Resilience in Post-Disaster Reconstruction: Towards a Resilient Development in Sichuan, China. International Journal of Disaster Risk Reduction 33 (2019) 376384.

Ride, A., Bretherton, D. 2011. Community Resilience in Natural Disasters. Palgrave Macmillan: United States.

Pasteur, K. 2011. From Vulnerability to Resilience: A framework for analysis and action to build community resilience. Practical Action Publishing.

Badan Nasional Penanggulangan Bencana (BNPB). 2009. Kajian Tentang Penanggulangan Bencana Alam Di Indonesia.

Peraturan Kepala Badan Nasional Penanggulangan Bencana (BNPB) Nomor 1 Tahun 2012 Tentang Pedoman Umum Kelurahan/Desa Tangguh Bencan

Zen, M.T, et.al (ed.). 2010. Mengelola Resiko Bencana di Negara Maritim Indonesia: Upaya Menguarangi Resiko Bencana (jilid 3). LPPM ITB

Cut, H., Muzar, H., Fithria., \& Syarifah, R. J. 2019. Efektivitas Edukasi Mitigasi Bencana terhadap Kesiapsiagaan Bencana Gempa Bumi dan Tsunami pada Keluarga Pasien di Rumah Sakit. Idea Nursing Journal, X, 2087-2879
Dwi, E., Mustikasari, \& Ria, U. P. 2020. Gambaran Post Traumatic Stress Disorder Pada Korban Bencana Alam Post Erupsi Merapi Satu Dekade. Jurnal Ilmu Keperawatan Jiwa, 3(2), 101-112.

Chatarina, R. 2012. Penanganan Dampak Sosial Psikologis Korban Bencana Merapi (Sosial Impact of Psychological Treatment Merapi Disaster Victims). Jurnal Informasi, 17(2).

Hasrul, H., Sri, A., \& Arnim, S. 2019. Penguatan Kesiapsiagaan Stakeholder Dalam Pengurangan Risiko Bencana Gempabumi. Jurnal Geodika, 3(1), 30-40.

Kusno, F., \& Uci, N. 2019. Efektifitas Pelatihan Penanggulangan Bencana Dengan Metode Simulasi Terhadap Perilaku Kesiapsiagaan Bencana Banjir Pada Siswa SMAN 2 Tuban. Jurnal Kesehatan Mesencephalon, 5(2), 88-94.

Ida, A.A.L., Putu, W.K.P., \& Kadek, I. A. 2019. Penerapan Pelatihan Siap Siaga Bencana (Sigana) Dalam Meningkatkan Kesiapsiagaan Bencana Pada Pecalang. Jurnal Pengabdian Kepada Masyarakat MATAPPA, 2(1).

Ramli, D., Sri, A.S., Sari, M., Dirhamsyah, M. 2014. Penerapan Pelatihan Siaga Bencana Dalam Meningkatkan Pengetahuan, Sikap, dan Tindakan Komunitas SMA Negeri 5 Banda Aceh. Jurnal Ilmu Kebencanaan (JIKA), 1(1).

Dewi, K. 2020. Komunikasi Mitigasi Bencana sebagai Kewaspadaan Masyarakat Menghadapi Bencana. Jurnal Simbolika, 6(1), 2442-9198.

Elyusra, U. 2013. Intervensi Spiritual Emotion Freedom Technique Untuk Menurunkan Gangguan Stres Pasca Trauma Erupsi Gunung Merapi. Journal of Educational, Health and Comunity Psychology, 2(1), 38-57.

Paramesti, C. A. 2011. Kesiapsiagaan Masyarakat Kawasan Teluk Pelabuhan Ratu terhadap Bencana Gempa Bumi dan Tsunami. Jurnal Perencanaan Wilayah Dan Kota, 22(2), 113-128.

Mariana, R., Fikri, H. T., Syahrina, I. A. 2020. Psikoedukasi Siaga Bencana: Membentuk Komunitas Sadar Bencana di Kawasan Wisata. Journal of Character Education Society, Vol. 3, No. 3, hal. 631-638.

Persada, C., Kesuma, Y., Rusmiat, F., dan Hardila, D. 2019. Pendampingan Masyarakat Tanggap Bencana di Kawasan Pariwisata Teluk Lampung Kabupaten Pesawaran. Draft Paper Pengabdian. 